\title{
Effects of sucrose and irradiance on germination and early gametophyte growth of the endangered tree fern Dicksonia sellowiana Hook (Dicksoniaceae) $)^{1}$
}

\author{
Gladys Daniela Rogge Renner ${ }^{2}$ and Áurea Maria Randi ${ }^{2,3}$
}

\author{
Received: November 11, 2002. Accepted: October 17, 2003
}

\begin{abstract}
RESUMO - (Efeito da sacarose e irradiância na germinação e crescimento inicial do gametófito da samambaia arbórea Dicksonia sellowiana Hook (Dicksoniaceae) em perigo de extinção). Esta samambaia arbórea ameaçada de extinção ocorre na floresta ombrófila mista, nos trópicos. Esporos esterilizados germinaram a $25 \pm 2^{\circ} \mathrm{C}$ em fotoperíodo de 16 horas, em meios de Dyer e MS, acrescidos de 0 a $5 \%$ de sacarose. A massa seca foi maior em gametófitos de 30 dias de idade, cultivados em meio Dyer com adição de 3\% a 5\% de sacarose e em meio MS com adição de $2 \%$ de sacarose. A massa seca diminuiu em gametófitos crescidos em meios Dyer e MS na ausência de sacarose e em meio MS acrescido de $5 \%$ de sacarose. O efeito de diferentes irradiâncias na germinação e desenvolvimento inicial de gametófitos foi analisado no outono de 1998 (de maio a julho). Frascos cônicos contendo esporos foram mantidos durante 49 dias dentro de caixas de $50 \mathrm{~cm}^{3}$ revestidas por telas que forneceram 5, 20,36 e 50\% de irradiância. Os menores tempos médios de germinação foram observados para esporos que germinaram sob 5 e $20 \%$ de irradiância Os mais altos níveis de clorofila total foram observados em gametófitos filamentosos cultivados sob 5 e $20 \%$ de irradiância durante 49 dias. Os maiores níveis de açúcares solúveis totais foram observados em gametófitos filamentosos cultivados a $20 \%$ de irradiância durante 49 dias.
\end{abstract}

Palavras-chave: açúcar, clorofila, gametófito, germinação, irradiância

\begin{abstract}
Effects of sucrose and irradiance on germination and early gametophyte growth of the endangered tree fern Dicksonia sellowiana Hook (Dicksoniaceae). It is an endangered tree fern that grows in mixed umbrophylus forests in the tropics. Sterilized spores were germinated at $25 \pm 2^{\circ} \mathrm{C}$ under a 16-hour photoperiod, in Dyer and MS medium supplemented with 0 to $5 \%$ sucrose. The germination was lower with the addition of sucrose. Dry mass was higher in 30-day-old gametophytes cultivated in Dyer medium with the addition of 3 to $5 \%$ of sucrose. The dry mass decreased in 30-day-old gametophytes cultivated in Dyer and MS media without sucrose and in MS medium with the addition of 4 or $5 \%$ of sucrose. The effect of different irradiance on the germination and early gametophyte development of D. sellowiana was analyzed in the autumn of 1998 (May until July). Conical flasks containing spores were kept over a period of 49 days in $50 \mathrm{~cm}^{3}$ boxes covered with black shade netting, which gave 5,20,36 and 50\% of irradiance. The lower mean germination time was observed for spores cultivated under $5 \%$ and $20 \%$ of irradiance. The highest chlorophyll content was recorded in gametophytes cultivated for 49 days under $20 \%$ and $5 \%$ of irradiance. The highest soluble sugar content was recorded in gametophytes cultivated under $5 \%$ and $20 \%$ of irradiance.
\end{abstract}

Key words: sugar, chlorophyll, gametophyte, germination, irradiance

\section{Introduction}

Dicksonia sellowiana Hook is an endangered tree fern belonging to the Dicksoniaceae family. It occurs throughout Central America from Venezuela to Colombia, Bolivia, Paraguay, Uruguay and Southeastern Brazil, were the trunks have been indiscriminately exploited by the commercialization of jars (Sehnem 1978; Tryon \& Tryon 1982).

According to Bernabe et al. (1999), understanding tree fern reproduction and establishment requirements could provide a basis for the development of alternative methods of propagation that may contribute to their conservation.

Light has signaling functions for any given plant's development in the forest and is the energy source for $\mathrm{CO}_{2}$ assimilation (Lüttge 1997). The germination of a great number of fern spores is promoted by light (Millër 1968). Nutrients as well as other factors are implicated in the growth and development of prothallus fern and in its sporophyte formation (Fernández et al. 1996; 1997).

\footnotetext{
1 Part of an MSc thesis of the first Author

2 Laboratory of Plant Physiology, Department of Botany, University Federal of Santa Catarina, CEP 88040-900, Florianópolis, SC, Brazil (amrandi@ccb.ufsc.br)

3 Corresponding Author: amrandi@ccb.ufsc.br
} 
Borelli et al. (1990) cultivated D. sellowiana spores in Jones and Knop (modified by Dyer) media and commented that the best results were obtained with decontamination carried out in a $2 \%$ sodium hypochlorite solution over a period of 10 or 20 minutes. Filippini et al. (1999) observed the lowest percentages of spore germination of $D$. sellowiana under 43 and $2 \%$ of irradiance.

In order to help elucidate the best conditions for the growth and early gametophyte development of D. sellowiana, we carried out two in vitro procedures. First, we investigated the effect of two mineral media, supplemented with sucrose. Second, we analyzed the effect of different levels of irradiance.

\section{Material and methods}

Sporophylls of D. sellowiana were harvested in March 1998 at the "Permanently Protected Area of Caraguatá" Antônio Carlos, Santa Catarina, Brazil. Sporophylls were air-dried in an oven at $30^{\circ} \mathrm{C}$ for three days on filter paper in order to induce dehiscence. The spores were removed and separated from sporangia by filtering through lens paper. They were then stored in glass jars under refrigeration at approximately $10^{\circ} \mathrm{C}$. The best sterilization method for fresh spores was that which employed surface sterilization using a 35\% (v/v) solution of commercial bleach ( $2 \%$ of active chlorine) for one hour before filtering through sterile filter paper and washing several times with sterile distilled water. For the germination tests, about $10 \mathrm{mg}$ of sterilized spores were sown in two conical flasks containing $20 \mathrm{ml}$ of autoclaved liquid medium. The flasks were plugged with two layers of autoclaved transparent commercial polypropylene film $(7 \times 7 \mathrm{~cm})$ fixed with rubber bands. All the procedures were carried out in a laminar hood. Spores were germinated in the following media: a) Dyer medium (Mohr modified by Dyer 1979) supplemented with Benlate ${ }^{\circledR} 0.01 \%$ and $0,1,2,3,4$ and $5 \%$ of sucrose (pH 5.8); b) Full-strength MS basal medium (Murashige \& Skoog 1962) supplemented with Benlate ${ }^{\circledR} 0.01 \%$ and sucrose $0,1,2,3,4,5 \%$ (pH 5.8). The germination was carried out in a growth room at $25 \pm 2^{\circ} \mathrm{C}$ under a 16-hour photoperiod, and a photon flux density of $32 \mu$ moles. $\mathrm{m}^{-2} \cdot \mathrm{s}^{-1}$, which was provided by cool white fluorescent tubes over a period of 21 days. The germination was scored after 14 and 21 days, and four slides were analyzed from each treatment with 100 spores counted on each slide.

To analyze early gametophyte development, 8 samples of sterilized spores (10mg each) were sown in conical flasks containing $20 \mathrm{ml}$ of each test medium in T1 (Time 1). After 30 days of cultivation as described above (Time 2), gametophyte dry mass was analyzed. After 30 days of cultivation gametophytes were in the filamentous phase. For dry mass determination, samples were dried in a microwave oven for a period of 2 minutes at high potency.

To study the effects of different irradiance on germination, trays containing two conical flasks in which surface sterilized spores had been sown were kept in $50 \mathrm{~cm}^{3}$ boxes covered with black shade netting giving $50,36,20$ and $5 \%$ of irradiance. The effects of different irradiance on germination and early gametophyte development were studied in the autumn of 1998 (May until early July) under environmental conditions. The levels of irradiance inside the boxes were analyzed by a LICOR 250 quantameter, fitted with a PAR sensor (400 to $700 \mathrm{~nm}$ ). The average of the photosynthetic photon flux density in May was $680 \mu$ moles. $\mathrm{m}^{-2} \cdot \mathrm{s}^{-1}$ at 2:00 $\mathrm{pm}$. The temperature average in May ranged from $16^{\circ} \mathrm{C}$ to $28^{\circ} \mathrm{C}$. Levels of chlorophyll and soluble sugars were analyzed in gametophytes cultivated over 49 days under different light intensities. Six replicates of known fresh weight (200mg each) were used for chlorophyll and soluble sugar extraction. Chlorophyll was extracted in acetone and was quantified according to Arnon (1949). Soluble sugars were extracted in MCW (methanol: chloroform: water12: $5: 3 \mathrm{v} / \mathrm{v}$ ) according to Shannon (1968) and quantified according to McCready et al. (1950).

Excel for Windows (Microsoft) and Statgraphics software were employed to analyze the data. The results of germination are expressed as percentages, but for the statistical analysis they were submitted to arcsine transformation in order to normalize the data. The means of 4 replications per treatment were compared by Multiple Range Test (Tukey p < 0.05) after angular transformation as suggested by Santana \& Ranal (2000). The mean germination time was calculated for each replication per treatment according to the equation: $\overline{\mathrm{t}}=\sum(\mathrm{tn}) / \sum \mathrm{n}$, where $\mathrm{t}$ is the time in days starting from day 0 , and $\mathrm{n}$ is the number of spores completing germination on day $\mathrm{t}$ (Labouriau 1983). These data were compared by Multiple Range Test (Tukey $\mathrm{p}<0.05$ ).

The percentage of increase/decrease in dry mass was calculated according to the equation T2 DM - T1 $\mathrm{DM}$, where $\mathrm{T} 2 \mathrm{DM}$ is the dry mass in time 2 (30 days of cultivation) and T1 DM is the initial dry mass estimated for the samples of $10 \mathrm{mg}$ of fresh spores. The T1 DM corresponded to $100 \%$. T2 DM (mg) was 
transformed to a percentage considering the initial dry mass (T1 DM). The Multiple Range Test (Tukey $\mathrm{p}<0.05$ ) was employed to compare dry mass, levels of chlorophyll and soluble sugars among treatments. Negative dry mass data were analyzed separately.

\section{Results and discussion}

The highest $D$. sellowiana germination was recorded after 14 days in Dyer medium without the addition of sucrose, but the germination was reduced in Dyer and MS media with the addition of sucrose (Fig. 1A) After 21 days, there was no difference between germination in Dyer and MS media without the addition of sucrose, but the germination was lower when the media were supplemented with 1 to $5 \%$ of sucrose (Fig. 1B). Spores of D. sellowiana survived
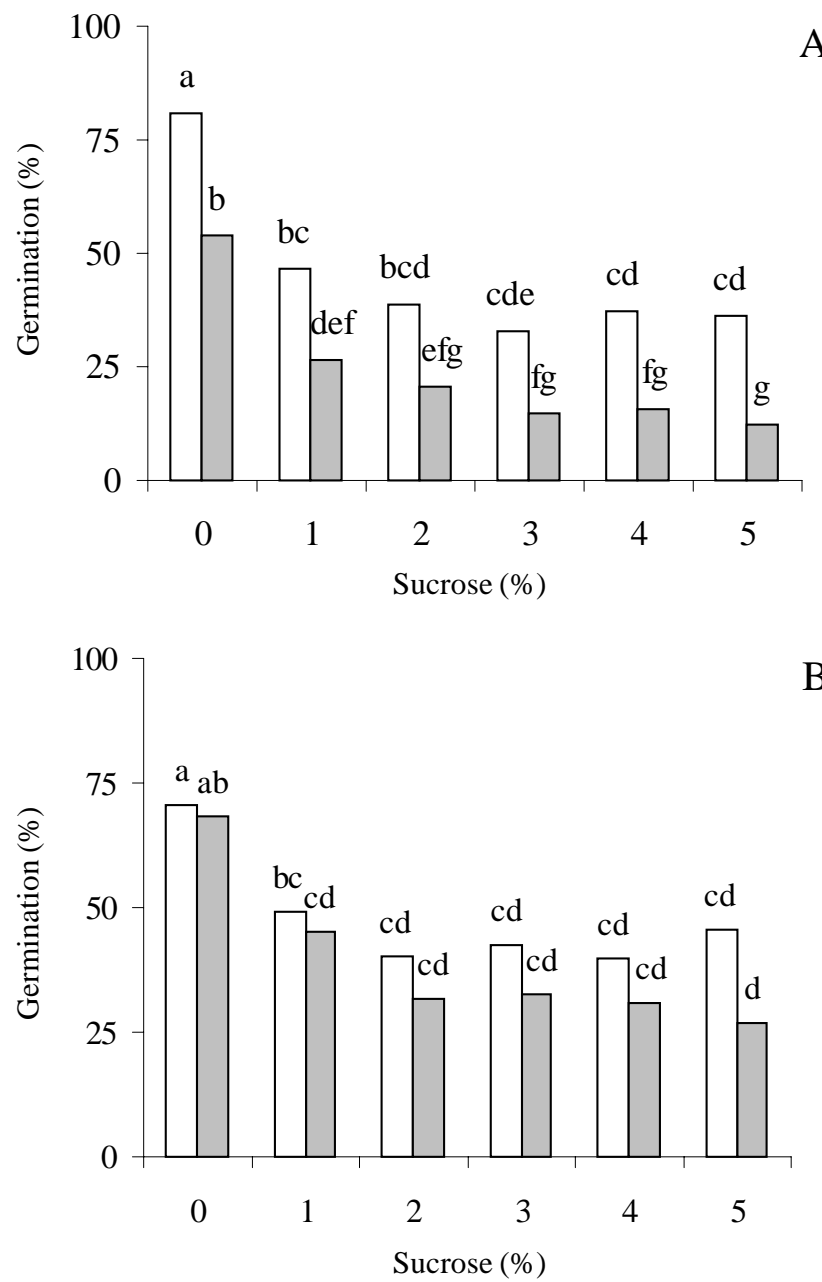

Figure 1. Germination of spores of Dicksonia sellowiana at $25 \pm 2^{\circ} \mathrm{C}$ under a 16 -hour photoperiod, after 14 days (A) and 21 days (B) of culture in Dyer and MS media supplemented with $1 \%$ to $5 \%$ of sucrose. Letters denote statistical differences (Tukey test $<0.05$ ) among treatments. $\square=$ Dyer; $\square=$ MS . after a rigorous sterilization procedure. It was obtained total decontamination and a high percentage of germination. On the other hand, Borelli et al. (1990) obtained 50\% contamination of D. sellowiana spores in $2 \%$ calcium hypochlorite solution. Raghavan (1989) reported that in general, liquid media were superior for fern spore germination and that it is likely that solid media prevents the breakage of spore coats. According to Camloh (1993), for spores of Platycerium bifurcatum (Cav.) C. Chr., liquid media are superior to solid media for early gametophyte development, but they have no effect on germination. Camloh (1993; 1999) also reported that the best germination occurred when unsterilized spores of $P$. bifurcatum were used, but that contamination always occurred after 10 days of culture, which was probably the reason for the lower cell number as compared to sterilized spores. Simabukuro et al. (1998) comment that before storing imbibed spores in the laboratory or before the germination of dry-stored spores, in order to avoid the incidence of fungal growth, there is the need to sterilize them. The same authors observed for Cyathea delgadii Sternb. that the elimination of bacterial and fungal contaminants was best when the spores were washed, treated with calcium hypochlorite, incubated, filtered and washed again before sowing on medium containing Nystatin.

The Dyer medium with the addition of 1 to $5 \%$ of sucrose and full strength MS basal medium with the addition of 1 to $4 \%$ of sucrose improved the fresh mass of 30-day-old gametophytes (Fig. 2A). Dry mass was higher in 30-day-old gametophytes cultivated in Dyer medium with the addition of 3 to $5 \%$ of sucrose and MS medium with $2 \%$ of sucrose, which was similar to Dyer medium with $4 \%$ of sucrose (Fig. 2B). However, there were no statistical differences among gametophyte's dry mass in MS medium with the addition of 1, 2 and 3\% of sucrose and Dyer medium with $2 \%$ of sucrose. Dry mass was reduced in gametophytes cultivated for 30 days in Dyer and MS medium without sucrose and in MS medium with the addition of 4 and 5\% of sucrose. (Fig. 2B). In Dyer and MS medium without sucrose, the reduction in the gametophyte's dry mass could be explained by the depletion of storage substances during germination and early gametophyte growth, as a consequence of respiratory activity and an insufficient photosynthetic rate to improve dry mass and biomass. The low MS osmotic potential ( $\Psi$ s) with the addition of 4 and 5\% of sucrose was probably able to prevent water uptake and consequently inhibit gametophyte metabolism thus 

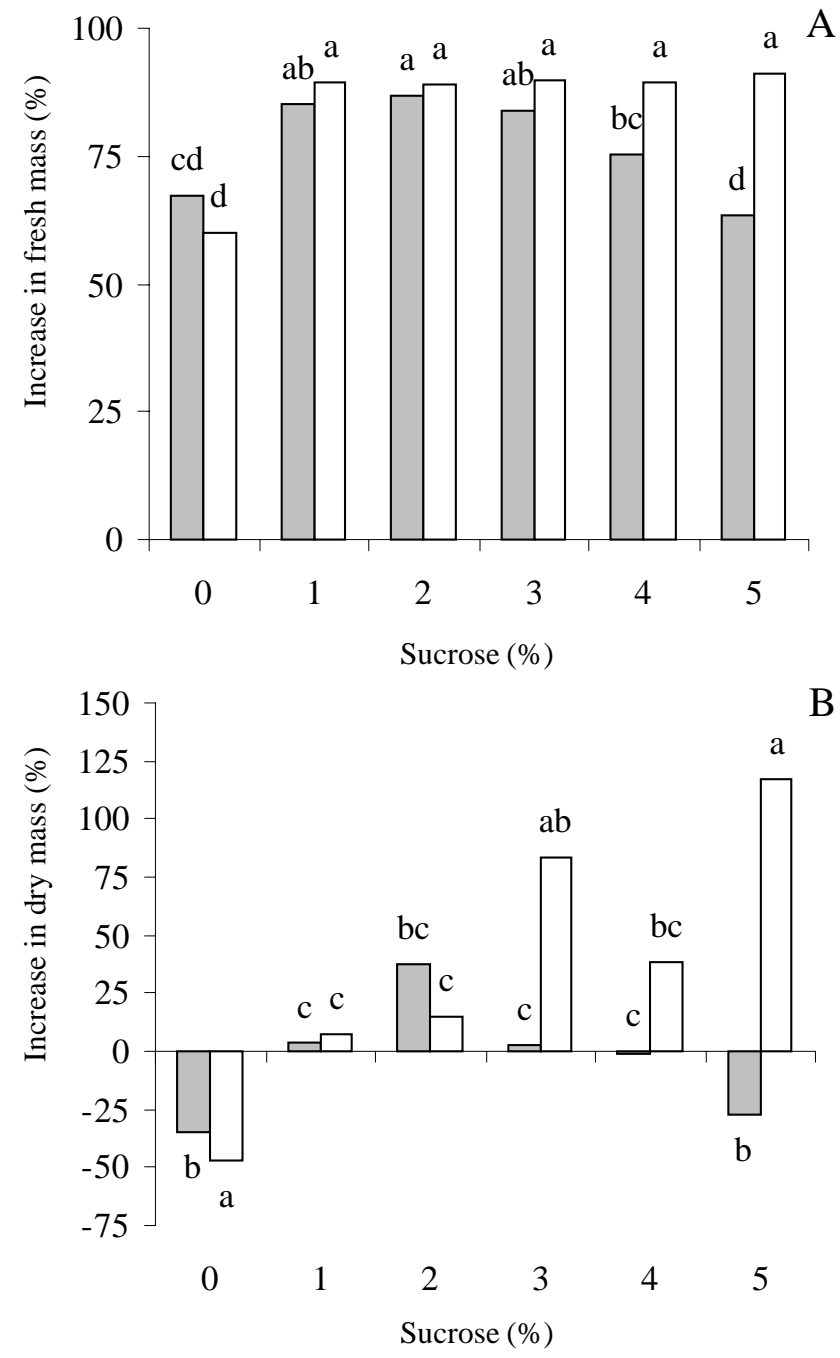

Figure 2. Variation in fresh mass (A) and dry mass (B) of 30-day-old gametophytes of Dicksonia sellowiana cultivated at $25 \pm 2^{\circ} \mathrm{C}$ under a 16-hour photoperiod, in Dyer and MS media supplemented with $1 \%$ to $5 \%$ of sucrose. Letters denote statistical differences (Tukey test< 0.05) among treatments. $\square=$ Dyer; $\square=$ MS.

reducing the dry mass through the respiratory metabolism. For $P$. bifurcatum, sucrose did not promote spore germination or early gametophyte growth, which is not the case for the growth of older gametophytes that give optimal growth with $4 \%$ of sucrose in the MS basal medium (Camloh \& Gogala 1992; Camloh 1993). On the other hand, for Osmunda regalis $\mathrm{L}$., the addition of sucrose inhibits, and manitol promotes, the growth and development of gametophytes (Fernández et al. 1997). Fernández et al. (1999) observed that the effect of sucrose on gametophyte development was dependent on the presence of mineral salts in the culture medium.

The highest chlorophyll content was observed in gametophytes cultivated under $5 \%$ and $20 \%$ of irradiance and the highest soluble sugar content in gametophytes cultivated under $20 \%$ of irradiance (Table 1). These data are in agreement with Yeh \& Wang (2000) who found the highest chlorophyll content in fronds of Adiantum raddianum cv. Fritz Luth under 92\% of shading. According to Lüttge (1997), shade plants contain higher total chlorophyll levels.

Table 1. Effect of irradiance on gametophyte chlorophyll and soluble sugars in Dicksonia sellowiana after 49 days of culture in liquid Dyer medium. FW - Fresh weight. Different letters denote statistical differences (Tukey $\mathrm{p}<0.05$ ) among treatments.

\begin{tabular}{ccc}
\hline $\begin{array}{c}\text { Irradiance } \\
(\%)\end{array}$ & $\begin{array}{c}\text { Total Chlorophyl } \\
(\mu \mathrm{g} / \mathrm{mg} \mathrm{FW})\end{array}$ & $\begin{array}{c}\text { Soluble sugars } \\
(\mu \mathrm{g} / \mathrm{mg} \mathrm{FW})\end{array}$ \\
\hline 50 & $4.07 \mathrm{a}$ & $1.38 \mathrm{a}$ \\
36 & $5.40 \mathrm{a}$ & $1.56 \mathrm{a}$ \\
20 & $7.62 \mathrm{~b}$ & $2.66 \mathrm{~b}$ \\
5 & $7.85 \mathrm{~b}$ & $1.19 \mathrm{a}$ \\
\hline
\end{tabular}

The effect of irradiance on spore germination was analyzed (Table 2, Figure 3). The lowest mean germination time $(\overline{\mathrm{t}})$ of $D$. sellowiana spores was achieved under $5 \%$ and $20 \%$ of irradiance. The germination of $D$. sellowiana spores was delayed under 50 and $36 \%$ of irradiance, after 14 and 21 days of culture in contrast to $20 \%$ and $5 \%$ of irradiance. This is the reason for the difference in the mean germination time. On the other hand, after 42 and 49 days of culture, statistical differences among treatments were not observed. Filippini et al. (1999) observed the highest percentages of $D$. selllowiana germination under similar irradiances. The germination of $R$. adiantiformis spores was completely inhibited under $72 \%$ and $54 \%$ of irradiance in March/2000, and partially inhibited under $72 \%$ of irradiance in April/2000. The lower mean germination time was achieved under $9 \%$ irradiance in April and August $/ 2000$ followed by $17 \%$ in August 2000

Table 2. Effect of irradiance on mean germination time $(\overline{\mathrm{t}})$ of Dicksonia sellowiana. Letters denote statistical differences among treatments (Tukey test, $\mathrm{p}<0.05$ ). i.c. = interval of confidence; $\mathrm{s}^{2}=$ variance of mean germination time .

\begin{tabular}{cccc}
\hline $\begin{array}{c}\text { Irradiance } \\
(\%)\end{array}$ & $\begin{array}{c}\text { Final germination }(\%) \\
\text { Mean } \pm \text { ic }\end{array}$ & $\overline{\mathrm{t}}$ (days) \pm i.c. & $\mathrm{s}^{2}$ \\
\hline 50 & $90.0 \pm 8.5$ & $39.15 \pm 0.75 \mathrm{~b}$ & 0.583 \\
36 & $91.5 \pm 4.3$ & $39.09 \pm 1.30 \mathrm{~b}$ & 1.751 \\
20 & $88.5 \pm 4.3$ & $34.18 \pm 0.43 \mathrm{a}$ & 0.189 \\
5 & $85.5 \pm 1,3$ & $34.27 \pm 0,33 \mathrm{a}$ & 0.112 \\
\hline
\end{tabular}




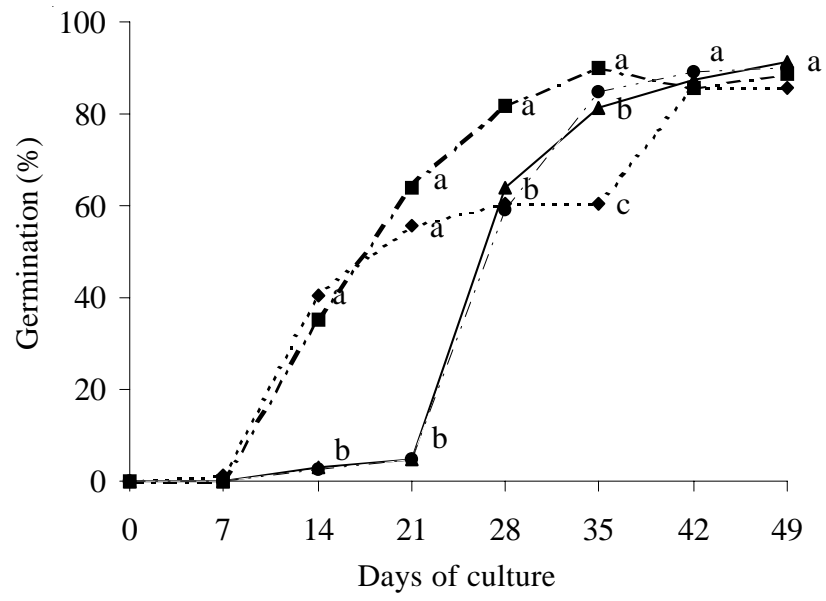

Figure 3. Effect of different levels of irradiance on the germination of Dicksonia sellowiana in Dyer medium. Letters denote statistical differences among treatments on each day of evaluation (Tukey test, p < 0.05). - - - = 5\%, - - - $=20 \%,-\boldsymbol{-}-=36 \%$, $--\bullet--=50 \%$.

(De Brum \& Randi 2002). Seeds of many species that need light to germinate can be inhibited by prolonged exposure to light, especially if the fluency is high. The photoinhibition of seed germination is a manifestation of the high-irradiance reaction (HIR) according to Bewley \& Black (1994). Shinomura et al. (1996) explain that seed germination of light-sensitive species is a low fluency response (LFR) controlled by the detection of changes in the red/far-red ratio (R/FR) through phytochrome B (PHY B). Similar partial photoinhibition could be proposed for spores of D. sellowiana under $50 \%$ and $36 \%$ of irradiance. Such behavior could guarantee gametophyte growth and reproduction, but only in appropriate environmental conditions where abundant water supply, low irradiance and mild temperatures are available

Our data showed that the germination of D. sellowiana was not improved when sucrose was added to the Dyer and MS mineral media, but that sucrose improved the dry mass of filamentous gametophyte. The lowest mean germination time was observed under 5\% and $20 \%$ of irradiance in May. These irradiances also provided the highest levels of the gametophyte's soluble sugar and chlorophyll.

\section{Acknowledgements}

To Paulo Sérgio Scheveitzer, manager of the "Permanently Protected Area of Caraguatá" SC, Brazil, for supplying plant material. The first Author thanks CAPES (Coordenadoria de Aperfeiçoamento do Pessoal de Ensino Superior - Brazil) for the grant.

\section{Bibliographic references}

Arnon, D.I. 1949. Copper enzymes in isolated chloroplasts. Polyphenoloxidase in Beta vulgaris. Plant Physiology 24: 1-15

Bewley, J.D. \& Black, M. 1994. Seeds: physiology of development and germination. Plennum Press, New York.

Bernabe, N.; Williams-Linera, G. \& Palacios-Rios, M. 1999. Tree ferns in the interior and at the edge of a Mexican Cloud Forest remnant: spore germination and sporophyte survival and establishment. Biotropica 31(1): 83-88

Borelli, F.P.; Castro, C.E.F.; Mathes, L.A.F.; Tombolato, A.F.C. \& Nagai, V. 1990. Propagação de pteridófitas in vitro e in vivo através de esporos. Bragantia 49(2): 206-209

Camloh, M. \& Gogala, N. 1992. In vitro culture of Platycerium bifurcatum gametophytes. Science Horticulture 51: 343-346.

Camloh, M. 1993. Spore germination and early gametophyte development of Platycerium bifurcatum. American Fern Journal 83(3): 79-85.

Camloh, M. 1999. Spore age and sterilization affect germination and early gametophyte development of Platycerium bifurcatum. American Fern Journal 89(2): 124-132.

De Brum, F.M.R. \& Randi, A.M. 2002. High irradiance and temperature inhibit the germination of spores of the fern Rumohra adiantiformis (Forst.) Ching (Dryopteridaceae). Revista Brasileira de Botânica 25(4): 391-396.

Dyer, A.F. 1979. The experimental biology of ferns. London, Academica.

Fernández, H.; Bertrand, A.M. \& Sanchez-Tames, R. 1996. Influence of tissue culture conditions on apogamy in Dryopteris affinis sp. affinis. Plant Cell Tissue and Organ Culture 45: 93-97.

Fernández, H.; Bertrand, A.M. \& Sanchez-Tames, R. 1997. Gemmation in cultured gametophytes of Osmunda regalis. Plant Cell Report 16: 358-362.

Fernández, H.; Bertrand, A.M. \& Sanchez-Tames, R. 1999. Biological and nutritional aspects involved in fern multiplication. Plant Cell Tissue and Organ Culture 56: $211-214$.

Filippini, E.C.P.; Duz, S.R. \& Randi, A.M. 1999. Light and storage in the germination of spores of Dicksonia sellowiana (Presl.) Hook., Dicksoniaceae. Revista Brasileira de Botânica 22(1): 21-26

Labouriau, L.G. 1983. A germinação das sementes. Série de Biologia, Monografia 24. Programa Regional de Desenvolvimento Científico e Tecnológico. Secretaria Geral da Organização dos Estados Americanos, Washington.

Lüttge, U. 1997. Physiological Ecology of Tropical Plants. Springer Berlin.

McCready, R.M.; Guggols, J.; Silviera, V. \& Owens, H. 1950. Determination of starch and amylose in vegetables. Annals of Chemistry 22: 1156-1158.

Millër, J.H. 1968. Fern gametophytes as experimental material. Botanical Review 34: 361-440.

Murashige, T. \& Skoog, F. 1962. A revised medium for rapid growth and bioassay tobacco tissue culture. Plant Physiology 15: 473-497

Raghavan, V. 1989. Developmental biology of fern gametophytes. Cambridge University Press, Cambridge. 
Santana, D.G. \& Ranal, M.A. 2000. Análise estatística na germinação. Revista Brasileira de Fisiologia Vegetal (Edição especial) 12: 205-237.

Sehnem, A.S.J. 1978. Ciateáceas. Flora Ilustrada Catarinense. Herbário Barbosa Rodrigues, Itajaí.

Shannon, J.C. 1968. A procedure for extraction and fractionation of carbohydrates from immature Zea mayz. kernels. Research Bulletin 842: 1-8.

Shinomura, T.; Nagatani, A.; Hanzawa, H.; Kubota, M.; Watanabe, M. \& Furuya, M. 1996. Action spectra for phytochrome A and phytochrome B specific photoinduction of seed germination in Arabidopsis thaliana. Proceedings of the National Academy of Sciences 93: 8129-8133.
Simabukuro, E.A.; Dyer, A.F. \& Felippe, G.M. 1998. The effect of sterilization and storage conditions on the viability of spores of Cyathea delgadii. American Fern Journal 88(2): 124-132.

Tryon, R. \& Tryon, A.F. 1982. Ferns and allied plants with special reference to Tropical America. Springer-Verlag New York.

Yeh, D.M. \& Wang, H.M. 2000. Effects of irradiance on growth net photosynthesis and indoor performance of the shade-adapted plant, maidenhair fern. Journal of Horticulture Science and Biotechnology 75(3): 293-29. 